\title{
Does Political Instability in Developing Countries Attract More Foreign Aid?
}

\author{
Mahjabeen Mamoon ${ }^{1}$ \\ ${ }^{1}$ School of Business and Economics (SBE), North South University, Dhaka, Bangladesh \\ Correspondence: Mahjabeen Mamoon, Lecturer, School of Business and Economics (SBE), North South \\ University, Dhaka 1229, Bangladesh. E-mail: Mahjabeen.mamoon@northsouth.edu
}

Received: August 20, 2015

doi:10.5539/ijef.v7n12p208
Accepted: November 23, 2015 Online Published: December 25, 2015

URL: http://dx.doi.org/10.5539/ijef.v7n12p208

\begin{abstract}
While foreign aid has many determinants, an important factor influencing aid allocation is the political risk prevailing in the aid receiving country. This paper uses panel approach to investigate empirically how different political instabilities in the aid receiving country influence aid allocation by donors. The paper specifies and estimates models using fixed effect and random effect approach that explain the allocation of net per capita ODA among 50 developing countries over the period 1990-2012. Out of the total eight risk indices used, five exerts a significant impact on aid allocation of which four are indicators of governance while the fifth is an indicator of internal conflict. Based on the models, there is a negative relationship between corruption and aid flow indicating donors' intolerance for malfeasance. However, the significantly positive association between aid flow and other three governance indicators- government stability, law and order and bureaucratic quality is questionable. While addressing the concept of governance in the development agenda reflects donors' increasing concern for aid effectiveness, the rise in aid inflow with the worsening of government stability, law and order and bureaucratic quality leads to one critical question- Are donors aiding bad governance? Based on the positive significance of poor governance and the insignificance of the socioeconomic condition on aid flow, the paper argues that donors are motivated by self-interest rather than altruistic nature.
\end{abstract}

Keywords: foreign aid, political instability, governance, panel data

\section{Introduction}

While the developing countries in practice may employ several strategies and methods to boost growth, an important and historical determinant of growth is foreign aid. According to World Bank Development Report (2005a) (Note 1) for many developing countries, foreign aid comprises a significant portion of the national income. In this paper, the relevant analytical question is to assess, how the existing political instabilities of the aid receiving countries effect donors' allocation of aid either directly or indirectly by interacting with the remaining determinants of foreign aid thereby shaping up foreign aid allocation.

According to Azam and Laffont (2003), foreign aid is viewed as a redistribution of resources from developed countries/donors to developing countries/recipients, motivated primarily by the donors' altruistic desire. In recent times, economists are taking into consideration additional donor motivations influenced by factors like trade openness of the recipient country, whether the recipient country is an exporter of oil or not, democratic or not, the volume of arms imports by the recipient countries and so on.

While these components play a crucial role in the model of aid allocation, an important issue that we cannot afford to ignore is the existence of instabilities and risks be it social, political or economic prevailing in the aid receiving countries that can affect the allocation of aid by donors. Thus an explanation of how political instability determines foreign aid can explain to a great extent why the volume of foreign aid received varies among the developing countries.

The rest of the paper is organized as follows. Section 2 summarizes briefly the literature on foreign aid and its connection with the recipient countries risk factors. Section 3 highlights the objective of the study. Section 4 presents the model specification of this paper as per the literature. The econometric results are set out and analyzed in Section 5. Section 6 is the concluding remarks. 


\section{Literature Review}

Official Development Assistance (ODA) has the potential of being allocated to recipients on the basis of needs. However, motivations for providing aid are often at odds and there is no guarantee that the poorest countries will receive a fair share of aid. Instead the allocation of aid can be dominated to a great extent by the instability of the recipient countries that hampers the true potential of foreign aid and also shapes up the donors strategic and economic interest in a way that is not always in favor of the recipient country.

The literature on aid distribution has given rise to various debates about the principles of aid allocation. Cline and Sargen (1975) pointed out that aid allocation that addresses recipients' needs also has to reward good economic performers/policies through positive incentives. McKinley and Little (1978) see foreign aid being allocated based on recipient countries need or donors strategic or political interest. We say a donor is motivated by strategic or political interests when an inefficient, economically closed, non-democratic former colony politically friendly to its former colonizer receives more foreign aid than another country with similar level of poverty and better policy stance.

Maizels and Nissanke (1984) concluded that while bilateral aid allocation was dominated by donors' strategic and commercial interest; multilateral aid was more influenced by the recipients' needs. (Note 2) Burnside and Dollar (2000) found that multilateral aid in particular World Bank aid considers recipients' "good economic policies" but that bilateral aid does not. In this respect, Alesina and Dollar (2000) also confirm that bilateral aid is based upon strategic considerations like the openness of the economy and the democratization process, whether the recipient is exporter of oil or not. In recent times, Collier and Dollar (2002) concluded that aid is poverty-efficient in a good policy environment.

Berthelemy (2006) conducted an empirical assessment to identify motivations behind ODA granted by the donors to the recipients. Results show that donors have both self-interest motive and development objective while allocating ODA.The fact that a bad economic environment is poverty inefficient suggests that countries that are more vulnerable must receive more aid showed by (Guillaumont \& Chauvet, 2001). This is where the debate lies-Donors' motivation in rewarding good economic environment versus donors compensating for vulnerable shocks.

Based on the above discussion of existing literature on aid allocation, it can be concluded that major determinants of aid allocation are: recipients' needs, merit, their vulnerability to external shock and donors' interest. These exogenous variables of the aid model suggest that there are both correct and incorrect incentives that motivate donors' allocation of aid. Correct incentives are the recipients' needs variable (per capita income of the recipient countries) and merit variables (openness and democracy) and incorrect incentives are donors' strategic interest (giving more aid to oil exporters, arms imports, colonial past).

It is a fact that an unstable economic, political and social environment is likely to act as a catalyst to increasing poverty. Empirical evidence presented by Venieris and Gupta (1986), Barro (1991) and Alesina et al. (1999) have successfully concluded that social, economic and political instability have negative impact on growth. If it is the case that the donors have an altruistic behavior then instability that leads to poverty has only one answer-increased aid. So if donors aim to reduce poverty then political instability should have a positive effect on the amount of aid received. If donors consider sociopolitical stability as a merit variable then high instability has a negative impact on aid allocation and more stability has a positive impact on aid allocation.

The third criteria of aid allocation is donors' strategic interest where the risk index is treated as an interest variable i.e. whether the sociopolitical events are beneficial to the donors or does it endanger donors' interest. This means that if the criterion of aid allocation is donors' interest, then any instability that threatens the donors' interest will create a negative impact on aid whereas instabilities that promote donors interest will raise foreign aid.

\section{Objective of the Study}

In this paper, focus will be limited to the disbursement of official development assistance. For convenience the paper classifies donors' attitudes towards recipient countries' political instability based on: the type of political risk component prevailing in the recipient country, recipient countries characteristics i.e. their per capita income, level of democracy, population and whether recipient country is an oil exporter.

Based on empirical and theoretical evidences in aid literature, the possible effects of political instability on aid allocation depending on the type of signal captured by each of this instability has been tabulated. This is illustrated in Appendix II.

The goal of this paper is to identify and quantify the impact of political instability on the allocation of aid by donors 
in presence of the main determinants of foreign aid. This paper addresses donors' attitude towards instabilities in terms of eight risk indices obtained from the International Country Risk Guide (ICRG) (Note 3). These indices are:

(1) Government Stability (2) Ethnic Tension (3) Law and Order (4) Bureaucratic Quality (5) Corruption (6) Military in Politics (7) Religion in Politics (8) Socioeconomic Condition.

\section{Model Specification}

The paper specifies and estimates models using fixed effect and random effect approach that explain the allocation of net per capita ODA among 50 developing countries (listed in Appendix I) over the period 1990-2012 (Note 4). The dependent variable used is Net ODA received per capita (constant 2011US\$). The relative aid variable is used following Maizels and Nissanke (1984); Trumbell and Wall (1994); Gounder (1994) and Chauvet (2002). Disbursements are used rather than commitment as they better reflect the actual resource being transferred.

According to the literature and empirics, donors are neither entirely selfish nor altruistic. Following Alesina and Dollar (2000); Neumayer (2003), recipients' need is captured by GDP per capita, PPP (constant 2011 international $\$$ ). Donors' strategic interest is captured by the variable titled oil exporter country which is constructed using dummy variables to denote membership of a recipient in the Organization of Petroleum Exporting Countries (OPEC).

Following Alesina and Dollar (2000); Chauvet (2002); recipients' merit is measured using two variables: trade openness proxied by trade as a percentage of GDP and democracy variable which has been lagged one period to avoid the simultaneity problem. Based on the insight of the fixed affect model, a regression equation of the following form has been specified:

$$
\ln A C A P_{i t}=\alpha_{i}+\beta_{1} R_{j i t}+\beta_{2} N_{i t}+\beta_{3} S_{i t}+\beta_{4} M_{i t}+\beta_{5} \ln P_{i t}+\varepsilon_{i t}
$$

$\mathrm{ACAP}_{\mathrm{it}}$ is the dependent aid per capita variable, $\mathrm{R}_{\mathrm{jit}}$ represents the risk indices ( $j$ denoting the kind of risk), $\mathrm{N}_{\mathrm{it}}$ is the set of recipient countries' needs, $S_{i t}$ are the donors strategic interest, $M_{i t}$ are the merit variables, $P_{i t}$ is recipient countries populations. Population as a variable is introduced to capture the bias in favor of small countries.

Based on the insight of the random effect model, I specify a regression equation of the following form:

$$
\ln A C A P_{i t}=\alpha+\beta_{1} R_{j i t}+\beta_{2} N_{i t}+\beta_{3} S_{i t}+\beta_{4} M_{i t}+\beta_{5} \ln P_{i t}+\mu_{i t}+\varepsilon_{i t}
$$

The variables denote the same meaning as equation 1 . The only difference is that in the equation for random effect there is an extra variable $\mu_{i t}$ and the intercept is constant.

\section{Empirical Results}

\subsection{Analyzing the Determinants of Foreign Aid}

In Table 1 and Table 2 the variables that report in all eight columns several times are the control variables. Oil exporter country (Note 5) as a variable has been introduced into the model to capture the donors' strategic interest. For all cases (1-8) under the random effect model reported in Table 2, a significantly positive coefficient for this variable instructively suggests that donors' strategic interest plays an important and influential role on the aid model. This result is consistent with the finding of (Chauvet, 2002).

The coefficient of the variable log of recipient countries per capita GDP (PPP adjusted) reported in Table 1 and Table 2 under both the models is negative with occasional significance in some cases. This implies as per capita GDP of the recipient rises, aid falls and vice versa indicating that donors are motivated by an altruistic nature too. This result is however inconsistent with (Alesina \& Dollar, 2000). They used initial income per capita both linearly and quadratically. The linear coefficient was positive and the squared one negative indicating that the amount of aid received is increasing in income but at a decreasing rate. Results are in line with (Maizels \& Nissanke, 1984) who concluded that multilateral aid was more influenced by the recipients' needs.

Population under both models is significantly negative indicating that small countries receive more aid per capita. This result is consistent with Alesina and Dollar (2000) and Chauvet (2002). Neumayer (2003) argued that the small population bias exist because donors might think that there would be a greater impact of aid allocation in small countries.

The next two variables in Table 1 and Table 2 are the merit variables: trade openness and Polity IV democracy variable. Democracy is an area where there are clear differences among major donors (Alesina \& Dollar, 2000). 
While the US, the Dutch, the UK, the Nordics and Canada have strong positive response to democratic institutions. Germany and Japan put little weight on this factor and France seems to pay no attention to the democracy of the receiving country at all.

In this paper, findings for the two merit variables: democracy and trade (as a $\%$ of GDP) is insignificant. The insignificant outcome of democracy is consistent with the findings of (Chauvet, 2002) but inconsistent with the findings of (Alesina \& Dollar, 2000). The finding of the second merit variable is also insignificant under both the models for all cases. This result is inconsistent with that of (Alesina \& Dollar, 2000) and (Burnside \& Dollar, 2000) who found a significantly positive impact of the openness variable in aid allocation estimation. On the ground of such insignificance of trade openness and democracy in the two models we can argue that donors are not rewarding or penalizing the recipients based on their merits or demerits

\subsection{Analyzing the Variables of Interest: Impact of Each Risk Index on Foreign Aid}

An important area of work lies in discussing the significance of the risk indices under the two models. In order to avoid the high multicollinearity problem, these indices are introduced separately into the one-way fixed effect and one-way random effect models. In this paper, high measure of every risk index represents high risk/instability and low measure represents low risk/instability.

\subsubsection{Measures of Governance: Government Stability, Law and Order, Bureaucratic Quality and Corruption}

Under both fixed effect and random effect model reported in Table 1 and Table 2, it is found that government stability, law and order and bureaucratic quality entails a significantly positive coefficient while corruption is associated with a significantly negative coefficient.

The index Government Stability (Note 6) (case 1) assesses government's ability to stay in office and carry out its declared programs. It is made up of three subcomponents- government's unity, legislative strength and popular support. In this paper, a high score equates to high risk indicating unstable government whereas a low score equates to low risk indicating stable government. The index is a potential outcome of governance where good governance is likely to allow government to stay longer in power while bad governance makes them stay shorter.

The index law and order (case 3) assesses the strength and impartiality of the legal system and an assessment of the popular observance of the law. Bureaucratic Quality (case 4) as an index measures the institutional strength/weakness of the bureaucracy which can create or absorb shock by increasing or decreasing revisions of policy when governments change. The index corruption (case 5) involves threat to foreign investment by distorting economic and financial environment, raising government inefficiency. Demanding special payments and bribes on import/export license, exchange control, tax assessment, police protection or loan are part of corruption.

The significantly positive relation of aid flow with case-1, case- 3 and case- 4 categorized as measures of governance altogether suggests that aid flow increases irrespective of worsening government stability, law and order and bureaucratic quality. This finding is consistent with (Neumayer, 2003). Chong and Gradstein (2008) also emphasized that aid inflow is less affected by the government efficiency of the aid receiving country. However, this finding is in conflict with Dollar and Levine (2006) who found that during the period of 2000-03, multilateral aid was significantly channeled to those countries with good governance.

According to Brautigum and Knack (2004), high levels of aid flow can relax the binding constraint of low revenue of the government, help them improve the quality of civil service, strengthen policy, planning capacity and establish strong central institutions. Taiwan, South Korea and Botswana are good examples. On this ground, more aid flow to countries having bad law and order system, faulty bureaucratic quality and unstable government seems justifiable.

Certainly good governance plays a major role in creating an efficient atmosphere for poverty reduction and growth. But the significantly positive association between aid flow and worsening bureaucratic quality, law and order, government stability found in this paper triggers one critical question- Are donors aiding bad governance because these recipient country governments are allowing donors to promote self-interest? Or is it that donors are stuck in a trade-off scenario between aid-supply and aid-effectiveness? Because what cannot be ignored is that countries that need aid most are those countries that have the worst level of governance leading to aid ineffectiveness. 
Table 1. Effect of risk indices on foreign aid under one-way fixed effect model from 1990-2012 (Case 1-Case 8)

\begin{tabular}{|c|c|c|c|c|c|c|c|c|}
\hline Dependent Variable: & 1 & 2 & 3 & 4 & 5 & 6 & 7 & 8 \\
\hline \multicolumn{9}{|l|}{ Ln net ODA per capita } \\
\hline \multirow[t]{2}{*}{ Constant } & 11.05 & 15.48 & 16.12 & 16.80 & 15.38 & 16.84 & 16.75 & 16.81 \\
\hline & $(4.39)^{*}$ & $(6.60)^{*}$ & $(6.89)^{*}$ & $(7.23)^{*}$ & $(6.35)^{*}$ & $(7.21)^{*}$ & $(7.17)^{*}$ & $(6.38)^{*}$ \\
\hline \multicolumn{9}{|l|}{ log Per capita GDP,PPP } \\
\hline & $(-1.35)$ & $(-1.85)^{* * *}$ & $(-1.55)$ & $(-0.84)$ & $(-1.65)^{* * *}$ & $(-1.89) * * *$ & $(-1.71)^{* * *}$ & $(-1.61)^{* * *}$ \\
\hline \multicolumn{9}{|l|}{ Ln Population } \\
\hline & $(-2.36)^{* *}$ & $(-3.91)^{*}$ & $(-4.25)^{*}$ & $(-4.82)^{*}$ & $(-3.69)^{*}$ & $(-4.27)^{*}$ & $(-4.35)^{*}$ & $(-3.74)^{*}$ \\
\hline \multicolumn{9}{|l|}{ Lag Democracy } \\
\hline & $(-0.31)$ & $(-0.45)$ & $(-0.35)$ & $(-0.31)$ & $(-0.55)$ & $(-0.58)$ & $(-0.49)$ & $(-0.49)$ \\
\hline \multicolumn{9}{|l|}{ Trade( $\%$ of GDP) } \\
\hline & $(0.30)$ & $(0.51)$ & $(0.46)$ & $(0.60)$ & $(0.87)$ & $(0.57)$ & $(0.59)$ & $(0.57)$ \\
\hline \multicolumn{9}{|l|}{ Government Stability } \\
\hline & $(5.55)^{*}$ & & & & & & & \\
\hline & & 0.092 & & & & & & \\
\hline \multirow[t]{2}{*}{ Ethnic Tension } & & $(3.70)^{*}$ & & & & & & \\
\hline & & & 0.063 & & & & & \\
\hline \multirow[t]{2}{*}{ Law \& Order } & & & $(2.63)^{*}$ & & & & & \\
\hline & & & & 0.119 & & & & \\
\hline \multirow[t]{2}{*}{ Bureaucratic Quality } & & & & $(3.43)^{*}$ & & & & \\
\hline & & & & & -0.058 & & & \\
\hline \multirow[t]{2}{*}{ Corruption } & & & & & $(-2.11)^{* *}$ & & & \\
\hline & & & & & & -0.022 & & \\
\hline \multirow[t]{3}{*}{ Military in Politics } & & & & & & $(-1.01)$ & & \\
\hline & & & & & & & 0.002 & \\
\hline & & & & & & & $(0.07)$ & \\
\hline \multicolumn{9}{|l|}{ Religion in Politics } \\
\hline \multicolumn{9}{|l|}{ Socioeconomic } \\
\hline \multirow[t]{2}{*}{ Condition } & & & & & & & & -0.0008 \\
\hline & & & & & & & & $(-0.04)$ \\
\hline $\mathrm{R}^{2}$ & 0.56 & 0.57 & 0.54 & 0.51 & 0.56 & 0.56 & 0.55 & 0.55 \\
\hline Observations & 1076 & 1076 & 1076 & 1076 & 1076 & 1076 & 1076 & 1076 \\
\hline Countries & 50 & 50 & 50 & 50 & 50 & 50 & 50 & 50 \\
\hline F-test statistic & 16.29 & 12.71 & 11.29 & 12.31 & 10.78 & 10.06 & 9.84 & 9.84 \\
\hline F-test (p-value) & 0 & 0 & 0 & 0 & 0 & 0 & 0 & 0 \\
\hline
\end{tabular}

Note. *significant at $10 \% ; * *$ significant at $5 \%$ level or better; *** significant at $1 \%$ level. 
Table 2. Effect of risk indices on foreign aid under one-way Random effect model from 1990-2012 (Case1-Case 8)

\begin{tabular}{|c|c|c|c|c|c|c|c|c|}
\hline Dependent Variable: & 1 & 2 & 3 & 4 & 5 & 6 & 7 & 8 \\
\hline \multicolumn{9}{|l|}{ Ln net ODA per capita } \\
\hline \multirow[t]{2}{*}{ Constant } & 13.22 & 14.55 & 14.37 & 13.85 & 14.64 & 15.02 & 14.91 & 14.82 \\
\hline & $(11.85)^{*}$ & $(13.46)^{*}$ & $(13.13)^{*}$ & $(12.28)^{*}$ & $(14.19)^{*}$ & $(13.80)^{*}$ & $(13.80)^{*}$ & $(13.74)^{*}$ \\
\hline \multirow[t]{3}{*}{ Oil Exporter } & 1.21 & 1.11 & 1.13 & 1.14 & 1.12 & 1.09 & 1.10 & 1.10 \\
\hline & $(4.36)^{*}$ & $(3.96)^{*}$ & $(4.04)^{*}$ & $(4.08)^{*}$ & $(4.31)^{*}$ & $(3.90)^{*}$ & $(3.98)^{*}$ & $(3.95)^{*}$ \\
\hline & -0.29 & -0.33 & -0.34 & -0.31 & -0.36 & -0.38 & -0.36 & -0.36 \\
\hline \multirow[t]{2}{*}{ log Per capita GDP,PPP } & $(-4.21)^{*}$ & $(-4.74)^{*}$ & $(-4.93)^{*}$ & $(-4.40)^{*}$ & $(-5.31)^{*}$ & $(-5.34)^{*}$ & $(-5.23)^{*}$ & $(-5.15)^{*}$ \\
\hline & -0.53 & -0.58 & -0.56 & -0.56 & -0.55 & -0.57 & -0.58 & -0.57 \\
\hline \multirow[t]{2}{*}{ Ln Population } & $(-10.16)^{*}$ & $(-11.24)^{*}$ & $(-10.90)^{*}$ & $(-10.90)^{*}$ & $(-11.31)^{*}$ & $(-11.00)^{*}$ & $(-11.09)^{*}$ & $(-10.88)^{*}$ \\
\hline & -0.0002 & -0.0005 & -0.0004 & 0.0004 & -0.0006 & -0.0007 & -0.0005 & -0.0006 \\
\hline \multirow[t]{2}{*}{ Lag Democracy } & $(-0.13)$ & $(-0.36)$ & $(-0.29)$ & $(-0.28)$ & $(-0.41)$ & $(-0.54)$ & $(-0.39)$ & $(-0.42)$ \\
\hline & 0.0014 & 0.001 & 0.0009 & 0.0009 & 0.0017 & 0.0009 & 0.001 & 0.001 \\
\hline Openness & (1.03) & $(0.76)$ & $(0.62)$ & $(0.63)$ & $(1.23)$ & $(0.65)$ & $(0.75)$ & $(0.70)$ \\
\hline \multirow[t]{3}{*}{ Government Stability } & 0.047 & & & & & & & \\
\hline & $(5.05)^{*}$ & & & & & & & \\
\hline & & 0.089 & & & & & & \\
\hline \multirow[t]{2}{*}{ Ethnic Tension } & & $(3.78)^{*}$ & & & & & & \\
\hline & & & 0.057 & & & & & \\
\hline \multirow[t]{2}{*}{ Law \& Order } & & & $(2.44)^{* *}$ & & & & & \\
\hline & & & & 0.098 & & & & \\
\hline \multirow[t]{2}{*}{ Bureaucratic Quality } & & & & $(2.94)^{*}$ & & & & \\
\hline & & & & & -0.062 & & & \\
\hline \multirow[t]{2}{*}{ Corruption } & & & & & $(-2.37)^{* *}$ & & & \\
\hline & & & & & & -0.029 & & \\
\hline \multirow[t]{2}{*}{ Military in Politics } & & & & & & $(-1.38)$ & & \\
\hline & & & & & & & 0.018 & \\
\hline Religion in Politics & & & & & & & $(0.67)$ & \\
\hline \multicolumn{9}{|l|}{ Socioeconomic } \\
\hline \multirow[t]{2}{*}{ Condition } & & & & & & & & -0.002 \\
\hline & & & & & & & & $(-0.14)$ \\
\hline $\mathrm{R}^{2}$ & 0.66 & 0.66 & 0.66 & 0.66 & 0.67 & 0.66 & 0.66 & 0.66 \\
\hline Observations & 1076 & 1076 & 1076 & 1076 & 1076 & 1076 & 1076 & 1076 \\
\hline Countries & 50 & 50 & 50 & 50 & 50 & 50 & 50 & 50 \\
\hline Wald chi2 & 255.09 & 239.81 & 232.01 & 234.97 & 262.2 & 228.36 & 229.48 & 226.25 \\
\hline Prob> chi 2 & 0 & 0 & 0 & 0 & 0 & 0 & 0 & 0 \\
\hline
\end{tabular}

Note. *significant at $10 \% ; * *$ significant at $5 \%$ level or better; *** significant at $1 \%$ level.

According to Knack (1999) and Busse and Groning (2009), inflow of foreign aid generates negative impact on governance and the outcome is robust to various model specifications. Based on this it can be argued that aid flowing to countries plagued with poor governance will only exacerbate the problem. Hence the recipients suffering from poor governance regarded as a catalyst to poverty, inequality and stagnating growth by receiving more aid would only remain trapped in a cycle of extreme poverty and sluggish economy. This argument has an interesting insight i.e. even if we ignore the debate between aid flowing to poor governance due to donors' interest versus aid flowing to poor governance for altruistic reason, the answer to poor governance should be clear- no aid or less aid. On this ground, allocation of more aid to countries practicing bad governance signals that donors' are driven by self-interest.

However, the fourth governance measure corruption (case 5) on aid contradicts the signal already generated by the above governance indicators. Corruption turned out to have a significantly negative influence on foreign aid i.e. more corrupted countries receive less aid and less corrupted countries receive more aid. In the literature it is found that unlike the large donors US, UK and Japan, the Scandavian countries give more aid to the less 
corrupted countries and less aid to the more corrupted aid receiving countries. It appears based on the model that unlike case 1, case 3 and case 4, corruption is treated as a merit variable of the recipient countries and aid is given based on this merit variable.

Indeed good governance creates a suitable environment for aid effectiveness. Whether countries receiving aid despite having poor governance are progressing in terms of the key governance indicators, whether aid is being channeled towards development effectively, whether donors' are aiding bad governance as guided by interest or are they driven by altruistic motive are all issues that demand critical examination and more analysis.

\subsubsection{Ethnic Tension}

An index used to proxy internal conflict is ethnic tension. It measures the degree of tension within a country due to diversity in race, nationality and language. The index turned out to exert a significantly positive influence on the allocation of foreign aid. According to Collier and Hoeffler (2002), ethnic tension is more common in developing countries. Literature suggests that if aid is sufficiently fungible into military expenditure then the government can exert more power to discourage such rebel groups and hence create a better environment for economic growth. Based on this argument a positive association between ethnic tension and aid flow seems justifiable and reflects donor's altruistic attitude.

However, according to Balla and Reinhardt (2008), proximity to conflict has a significantly positive impact on ODA allocation. Clearly national security being the forefront of policy any donor would always try to get rid of unrest originating in the nearby developing countries. Thus it is ambiguous whether this index signals donors' strategic motive or altruistic behavior.

\subsubsection{Military in Politics, Religion in Politics, and Socioeconomic Condition}

Theoretically, the risk indices-Military in Politics (case 6) and Religion in Politics (case 7) are treated as a merit/demerit variable where huge involvement of military or religion in politics are expected to disrupt democracy, good governance system thereby hampering political right and civil liberty in particular. Another index Socioeconomic Condition (case 8) could be treated as a need variable or a merit variable by the donors. It is assessed based on three sub components- unemployment, consumer confidence and poverty.

Insignificance of all these three indices- military in politics, religion in politics and socioeconomic condition under the two models used suggest that they exert no influence in donors' allocation of aid. Based on this we can once again argue that donors are indifferent towards recipients experiencing autocracy, lack of civil liberty or political right. The fact that the genuine purpose of ODA only lies in addressing the need of the poor nation can be ruled out completely based on the analysis of Socioeconomic Condition (case 8). Insignificant relationship between aid inflow and this index signals donors' reluctant behavior towards crucial factors like poverty and unemployment while allocating aid.

\subsection{Comparative Testing: Fixed Effect Model versus Random Effect Model}

Of the eight regression cases conducted, five risk indices were significant with same sign under both Fixed Effect Model and Random Effect Model. A comparative testing called the Hausman Specification Test is used to find out which is the preferred model for these five cases of risk indices that exerts a significant influence on aid. The null hypothesis is that the preferred model is random effect so that every time we have a significant outcome we reject the null hypothesis and say that the preferred model is fixed effect. According to Hausman Test Results, for all the five risk indices exerting significant influence on aid, the preferred model is the Random Effect Model.

\section{Conclusion}

The objective of this paper is to evaluate the impact of recipient countries political instabilities on the allocation of Official Development Assistance (ODA) by donors. An intensive literature study on aid allocation has revealed that all the eight risk indices used either directly or indirectly have some effect on the donors' allocation of aid. However, the difference lies in the magnitude of impact. Similarly whereas the existence of some may encourage the aid flow, the existence of some others discourages it.

The hypothesis of this paper is that instabilities of the aid receiving countries influence aid allocation. This is supported by the panel regression-based evidence. Of the eight risk indices used, five exerted significant impact on aid allocation. Thus we can emphasize that political risk factors strongly determine the disbursement of Official Development Assistance (ODA).

While the significantly negative coefficient of corruption indicates that there is zero tolerance for malfeasance, the rise in aid flow with a declining government stability, poor law and order and appalling bureaucratic quality 
triggers a critical question-Are Donors Aiding Bad Governance because these recipient country governments are allowing donors' promote self-interest? Based on empirical literature it is argued that allocation of more aid to countries plagued by bad governance signals how donors are driven by self-interest. At the same time the insignificance of the index socioeconomic condition on aid disbursement in the two models of the paper further implies donors' ignorance towards recipients' need.

Certainly giving aid to the poorer nations may be viewed as a moral responsibility and in many instances may appear to be motivated by altruistic reasons only but we cannot rule out the idea that aid allocation in many instances are guided by donors' self-interest. In this context donors would rather behave like investors where by allocating aid they try to attain recipients' support for promoting donors' interests in the sphere of international politics or generate sufficient demand for the exports of the donors' thereby building stable trading partnership between the donors and the recipients.

\section{Acknowledgements}

I would like to express my deepest gratitude to Professor Gour Gobinda Goswami for his expert advice and comments that helped me conduct the empirical analysis of this paper successfully. I was fortunate enough to have him as my supervisor in my undergraduate program where he was the first one to instill research interest in me and taught me how to maintain high research standards. I would also like to thank Sheikh Mohammad Sayem who during the course of this research guided me frequently with numerous insights on various issues in econometrics. Finally, I would like to thank Mahmuda Shaila for her time and effort to check the manuscript.

\section{References}

Alesina, A., Easterly, W., \& Baqir, R. (1999). Public Goods and Ethnic Divisions. Quarterly Journal of Economics, 114(4), 1243-1284. http://dx.doi.org/10.1162/003355399556269

Alesina, A., \& Dollar, D. (2000). Who gives foreign aid to whom and why. Journal of Economic Growth, 5, 33-64. http://dx.doi.org/10.1023/A:1009874203400

Azam, J. P., \& Laffont, J. J. (2003). Contracting for aid. Journal of Development Economics, 70(1), 25-58. http://dx.doi.org/10.1016/S0304-3878(02)00085-8

Barro, R. (1991). Economic growth in a cross-section of countries. Quarterly Journal of Economics, 106(2), 407-444. http://dx.doi.org/10.2307/2937943

Balla, E., \& Reinhardt, G. Y. (2008). Giving and Receiving Foreign Aid: Does Conflict Count? World Development, 36(12), 2566-2585. http://dx.doi.org/10.1016/j.worlddev.2008.03.008

Berthélemy, J. C. (2006). Bilateral donors' interest vs. recipients' development motives in aid allocation: Do all donors behave the same? Review of Development Economics, 10(2), 179-194. http://dx.doi.org/10.1111/j.1467-9361.2006.00311.x

Brautigam, D., \& Knack, S. (2004). Foreign Aid, Institutions, and Governance in Sub-Saharan Africa. Economic Development and Cultural Change, 52(2), 255. http://dx.doi.org/10.1086/380592

Burnside, C., \& Dollar, D. (2000). Aid, Policies \& Growth. American Economic Review, 90(4), 847-868. http://dx.doi.org/10.1257/aer.90.4.847

Busse, M., \& Groning, S. (2009). Does Foreign Aid Improve Governance? Economic Letters, 104, 76-78. http://dx.doi.org/10.1016/j.econlet.2009.04.002

Chauvet, L. (2002). Socio-political instability \& the allocation of international aid by donors. European Journal of Political Economy, 9, 33-59. http://dx.doi.org/10.1016/S0176-2680(02)00128-3

Chong, A., \& Gradstein, M. (2008). What determines foreign aid? The donors' perspective. Journal of Development Economics, 87, 1-13. http://dx.doi.org/10.1016/j.jdeveco.2007.08.001

Cline, W. R., \& Sargen, N. P. (1975). Performance criteria and multilateral aid allocation. World Development, 3, 383-391. http://dx.doi.org/10.1016/0305-750X(75)90023-6

Collier, P., \& Dollar, D. (2002). Aid allocation and poverty reduction. European Economic Review, 46, 1475-1500. http://dx.doi.org/10.1016/S0014-2921(01)00187-8

Collier, P., \& Hoeffler, A. (2002). Aid, Policy and Peace: Reducing the Risks of Civil Conflict. Defense and Peace Economics, 13, 435-450. http://dx.doi.org/10.1080/10242690214335

Dollar, D., \& Levin, V. (2006). Increasing Selectivity of Foreign Aid, 1984-2003. World Development, 34(12), 2034-2046. http://dx.doi.org/10.1016/j.worlddev.2006.06.002 
Gounder, R. (1994). Empirical results of aid motivations: Australia's bilateral aid program. World Development, 22, 99-113. http://dx.doi.org/10.1016/0305-750X(94)90171-6

Guillaumont, P., \& Chauvet, L. (2001). Aid and performance: a reassessment. Journal of Development Studies, 37, 66-92. http://dx.doi.org/10.1080/713601083

Knack, S. (1999). Aid dependence and the quality of governance: A cross country empirical analysis. IRIS University of Maryland. http://dx.doi.org/10.1596/1813-9450-2396

Maizels, A., \& Nissanke, M. (1984). Motivations for Development Aid to Developing Countries. World Development, 12(9), 879-900. http://dx.doi.org/10.1016/0305-750X(84)90046-9

McKinley, R. D., \& Little, R. (1978). The French aid relationship: A foreign policy model of the distribution of French bilateral aid, 1964-1970. Development and Change, 9, 459-478. http://dx.doi.org/10.1111/j.1467-7660.1978.tb00772.x

Neumayer, E. (2003). The Pattern of Aid Giving: The Impact of Good Governance on Development Assistance. Routledge Studies in Development Economics, London. http://dx.doi.org/10.4324/9780203986837.fmatt

Trumbull, W. N., \& Wall, H. J. (1994). Estimating aid-allocation criteria with panel data. Economic Journal, 104, 876-882. http://dx.doi.org/10.2307/2234981

Venieris, Y. P., \& Gupta, D. K. (1986). Income distribution and sociopolitical instability as determinants of savings: Across-sectional model. Journal of Political Economy, 94, 873-883. http://dx.doi.org/10.1086/261412

World Bank. (2005). World Development Report: A Better Investment Climate for Everyone. Washington, D.C: A co-publication of the World Bank and Oxford University Press.

\section{Notes}

Note 1. Multilateral ODA has grown over the past 20 years. In 2011, it reached almost USD 38 billion income resources.

Note 2. Alesina and Dollar (2000) also argued that when we consider bilateral aid allocation economic/ strategic interests must be taken into account besides poverty reduction.

Note 3. Details on each of these political risks rating of the indices used can be found from the International Country Risk Guide (ICRG) under the PRS Group.

Note 4. Most of the data are drawn from the World Bank's World Development Indicators \& the International Country Risk Guide (ICRG) published by the PRS Group.

Note 5. It must be noted that the variable oil exporter countries used by dummies to indicate whether the recipient country is an oil exporter or not has been dropped from the fixed effect model as it doesn't vary within the country.

Note 6. The index Government Stability is an assessment of the government's ability to stay in office and carry out its declared program.

\section{Copyrights}

Copyright for this article is retained by the author(s), with first publication rights granted to the journal.

This is an open-access article distributed under the terms and conditions of the Creative Commons Attribution license (http://creativecommons.org/licenses/by/3.0/). 